\title{
Building limes for cultural heritage conservation in China
}

Shi-bing Dai

\begin{abstract}
Introduction: Lime has been used as a building and decoration material for thousands of years in China. Recent research has focused on developing new air lime with higher bonding strength, grouts and restoration mortars etc. based on natural hydraulic lime, which is both chemically and mechanically more compatible with historic substances.

Results: The most applied lime in China was, and is still air lime, and the traditional slaking and preparation technique has been passed over to the modern generation for most restoration projects. Optimum dosage of Tungoil to lime-earth as damp proofing barrier lies at app. $5 \mathrm{wt} \%$. A kind of patented dispersed air lime modified with additives has been developed, which can be applied as a binder for restoration of traditional lime ornaments or lime paints. Natural hydraulic lime has been introduced into China from 2008 Recently, adhesives and grouting slurries based on natural hydraulic lime have been developed and applied for refitting and cavity filling of delaminated cultural surfaces with proven satisfaction.

Conclusion: The preliminary research works show, both air lime and natural hydraulic limes through modification of latest construction chemistry achievements can meet most of restoration requirements.
\end{abstract}

Keywords: Building lime, Cultural heritage conservation, Natural hydraulic lime, Adhesive, Grouting, Restoration mortar

\section{Introduction}

In the summer of 1998, during the international conference on conservation of Yungang Grottoes (listed as UNESCO cultural heritage in December 2001), Prof. Dr. Gunter Strübel from Justus-Liebig-Universität Giessen Germany introduced the latest results on the application of natural hydraulic limes (NHL) in conservation and restoration of cultural heritage which was sponsored by the Bundesstiftung für Umwelt (DBU) [1,2]. His lecture, however, didn't cause many responses from Chinese colleagues. 10 years later, while conserving Huashan Pictographs in Ningming, Guangxi Autonomy under the leadership of China National Academy for Cultural Heritage, conservators met with difficulties in restoring cracked and delaminated lime stones. In order to find compatible conservation materials, comprehensive and extensive research works have been carried out. Materials and application methods for refitting and

Correspondence: ds_build@163.com

Architecture Conservation Laboratory, CAUP of Tongji University, Room 113 Wenyuan Building, No. 1239, Siping Road, Shanghai CN-200092, PR China strengthening delaminated natural stones on the basis of natural hydraulic lime have broken through [3-7]. From 2008, natural hydraulic limes have been introduced into China and selectively used to strengthen and restore historic architecture and monuments like Huashan pictographs (Figure 1) in Guangxi and restoration of marble stones of Golden Bridge in front of Tiananmen of Forbidden City in Beijing (Figure 2). In recent years, natural hydraulic limes have become popular materials in the field of cultural heritage conservation and over 5 research and development projects have been launched by the China National Bureau for Cultural Heritage. However, there are still misunderstandings about its definitions, specification, properties and durability for the conservation of cultural heritage.

Basing on the research of lime materials in China over the past two decades, this paper summarizes some of the latest achievements in research and development of lime, especially natural hydraulic lime, for conservation and restoration of cultural heritage in China under the 


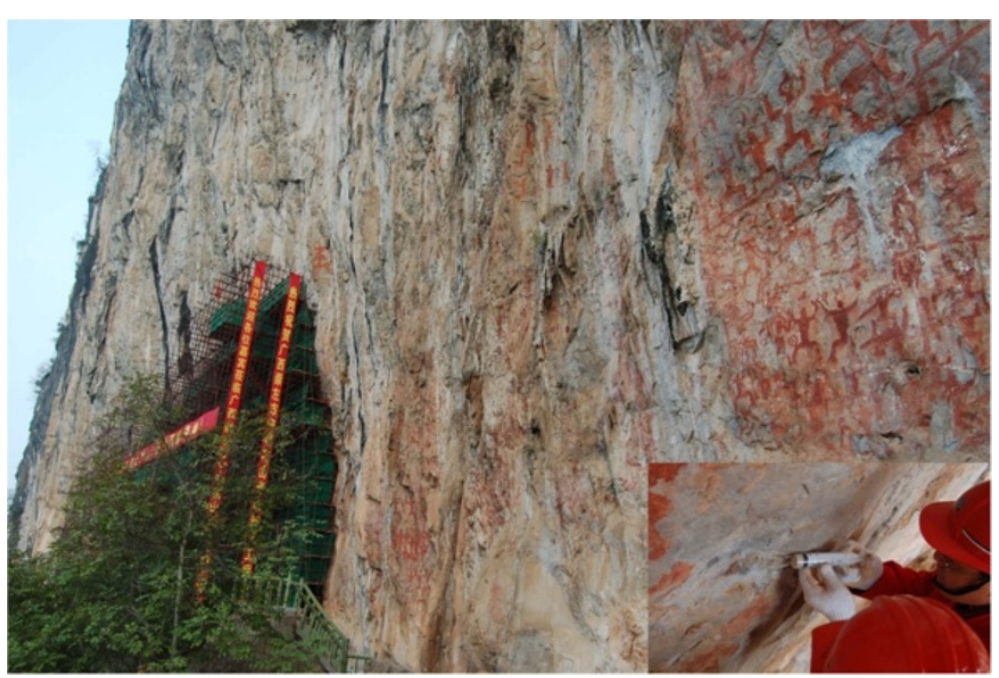

Figure 1 Conservation of Huashan Pictographs during 2009-2013 using natural hydraulic limes as raw material, Guangxi Autonomy.

funding of several national and international research projects.

\section{Traditional slaking and preparation of lime in China}

Lime has been used as a building and decoration material for thousands of years in China [8,9]. However quick lime was in most cases slaked wet, only in coastal region, quick lime kilned from oyster shells was slaked dry, but without any grinding. This may be one of the reasons why the term "hydraulic lime" was translated into China as early as 1950 's, but not understandable and applied by most technicians.
Today traditional slaking and preparation technique can still be observed in heritage conservation sites [10]. During so called "Southern Shanxi Projects", which were started from 2006, and over 100 heritage architectural temples and settlements erected before Yuan Dynasty (before 1206) are being restored, quick lime is slaked wet. Lime putty is mixed with addition of hemp, earth and pigments for masonring and roofing (Figure 3).

Tempering is also a traditional preparation technique in southern China to get very smooth crack-free marbleimitated top lime plaster finishing (Figure 4).

Like in Europe [11], hot lime is being also tried to restore natural stone architecture and ornament earthen

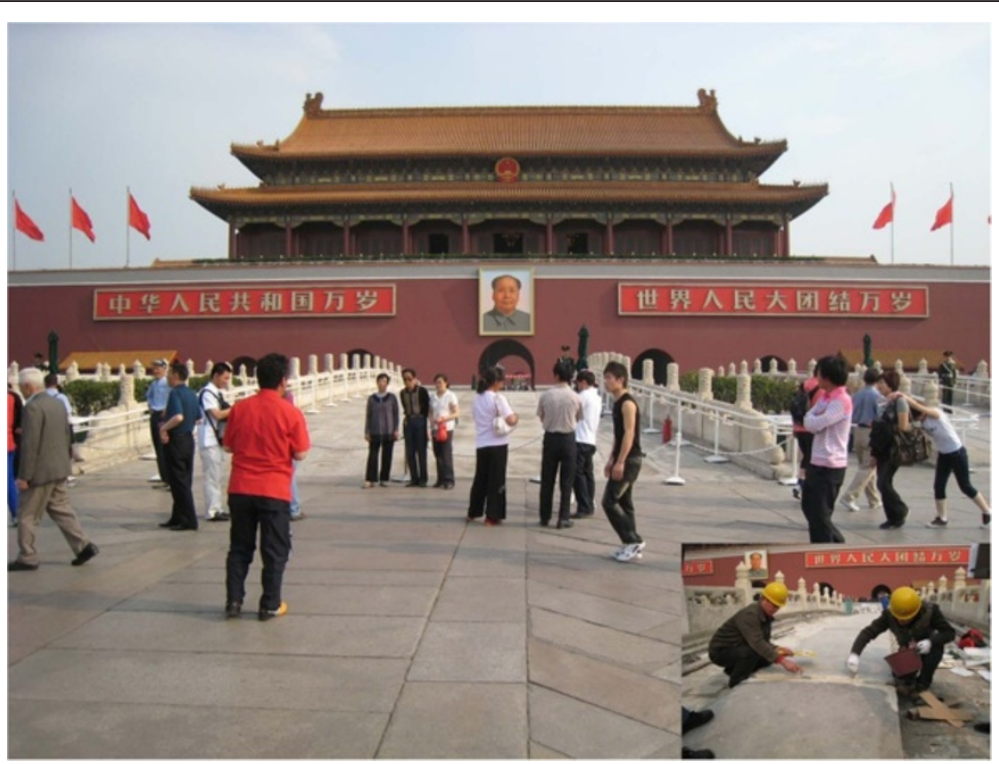

Figure 2 Marble restoration of Golden Bridge in front of Tiananmen Beijing, using NHL2 in 2009 (right) and after restoration (left). 


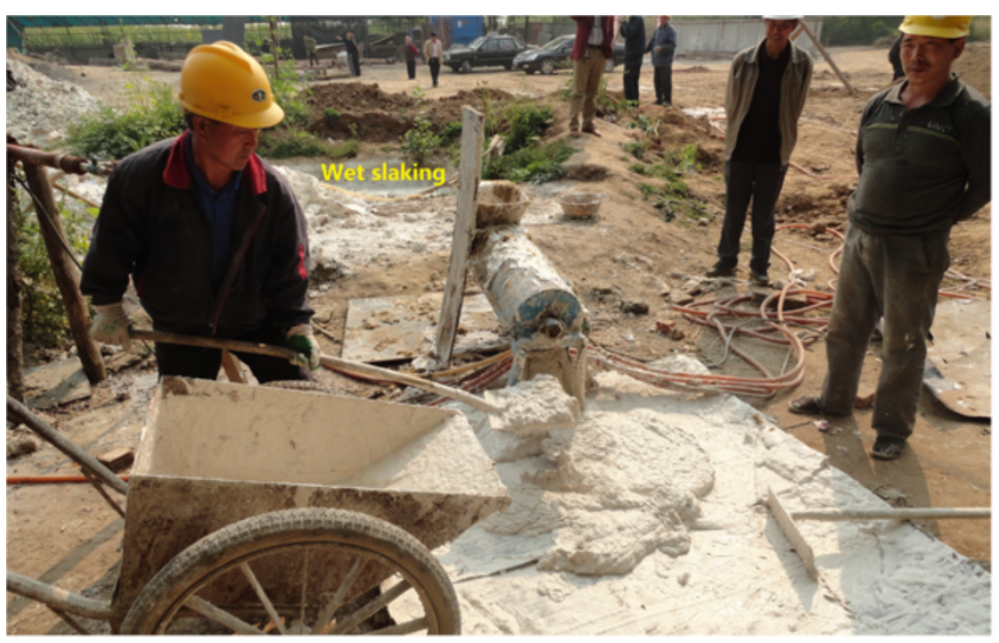

Figure 3 Wet slaking and preparation of lime with hemp fibers during restoration works in southern Shanxi 2012.

elements. During restoration of Bell Tower Beijing in 2010, quick lime was slaked to form lime milk according to traditional lime slaking technique to seal voids and joints by pouring into cracks immediately after slaking. The subsequent expansion of freshly slaked quick lime milk compensates the shrinkage of pure lime grout.

During the survey of heritage architecture in Jinggangshan region of Jiangxi Province, it has been told that Tungoil, a kind of natural oil from tree nut in Southchina, was mixed into earth as damp proofing barrier (Figure 5). No organic remaining, however, have been identified in the samples taken from the basements and floors. To prove the legendary tradition and optimize the dosage, lime-earth mixture composed of $10 \mathrm{wt} \%$ calcium hydrate (CL), $10 \mathrm{wt} \%$ natural hydraulic lime (NHL2, Hessler Kalk Germany), 20\% sieved river sand $(0.25-0.60 \mathrm{~mm})$ and $60 \mathrm{wt} \%$ clay rich earth was compacted with 0-15 wt\% raw Tungoil. The compacted samples were sealed with polyethylene sheet and stored under water for 14 days. Then the capillary water uptake according to DIN 52617 was measured. The results show that the Tungoil reduces the water uptake and optimum dosage lies at app. $5 \mathrm{wt} \%$ (Figure 6). The higher dosage causes instead higher water absorption; this may be explained that high content of Tungoil may have disturbed the chemical reaction between lime and clay minerals. The damaged foundation of the earth-timber heritage architecture in Jingangshan region is being restored based on this formulation.

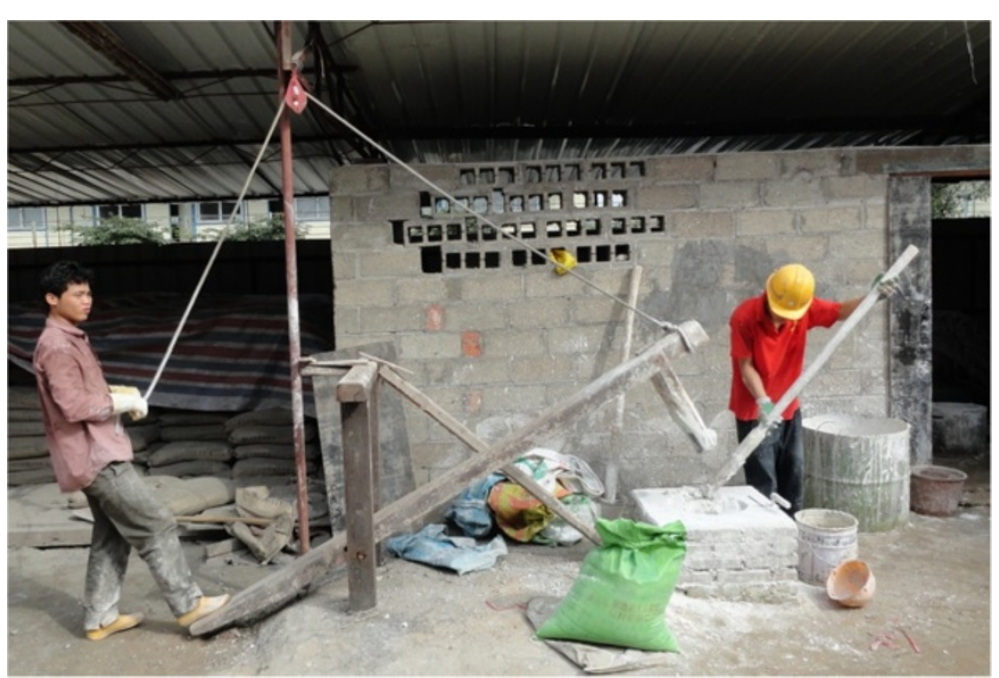

Figure 4 Preparation of lime plaster finishing by tempering for façade restoration in Haikou 2011. 


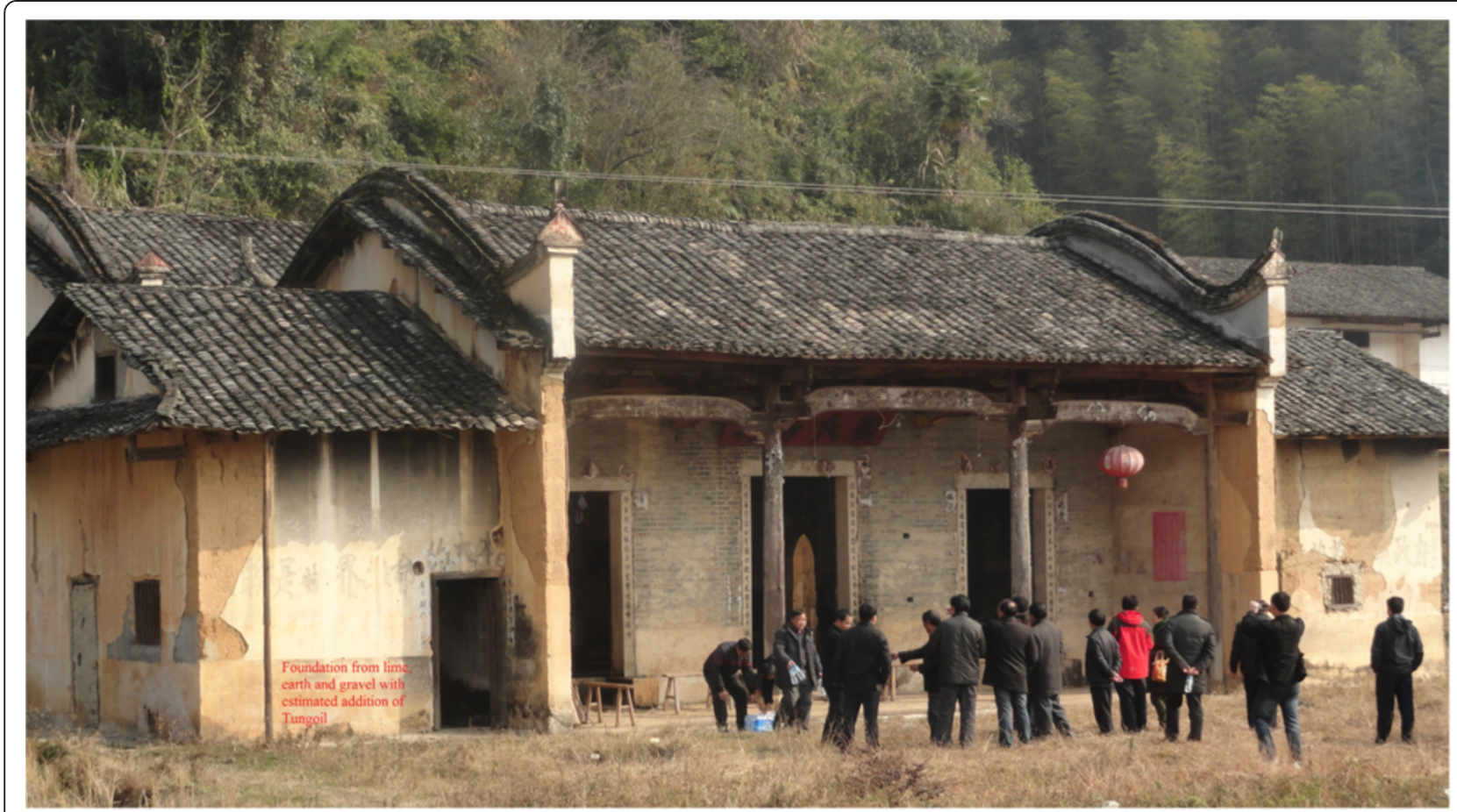

Figure 5 Traditional earthen-timber architecture built in 1824 with foundation from lime, earth and gravel with estimated addition of Tungoil in Jiangxi Province.

\section{Building lime standards in China}

In 2010, new European building lime standard EN459-1, modified from previous version, was published [12]. Comparing to old version, natural hydraulic lime (NHL), formulated lime (FL) and hydraulic lime (HL) under the category of limes with hydraulic properties has been clearly specified. Natural hydraulic lime, its use can be dated back to Romans [13], is a lime with hydraulic properties produced by burning of more or less argillaceous or siliceous limestones with reduction to powder

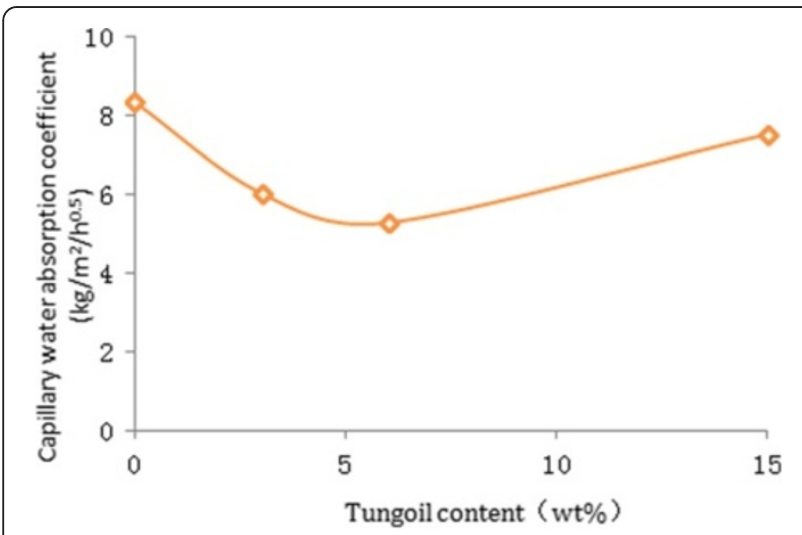

Figure 6 Relationship between capillary water uptake of limeearth mixture and Tungoil content. by slaking with or without grinding. No other additions are allowed except grinding agents up to $0.1 \mathrm{wt} \%$. Hydraulic lime is, however, a binder consisting of lime and other materials such as cement, blast furnace slag, fly ash, limestone filler and other suitable materials, but does not need to have a declaration of constituents. Formulated lime (FL), which is a new term, is a lime with hydraulic properties mainly consisting of air lime (CL) and/or natural hydraulic lime (NHL) with added hydraulic and/or pozzolanic material. To protect the user especially in restoration and conservation, formulated limes contain a constituent's declaration.

The advantages of NHL are low strength; low content of water soluble salts, but it has also disadvantages, for example, not frost resistant if it is not completely carbonated. One of main disadvantages of HL is the fast hardening, which may cause tension cracking between historic substances and new materials. FL shall bridge the gap between NHL and HL.

In the USA, new ASTM standard for hydrated hydraulic lime for structural purpose was also published in 2009.

The latest building lime standard in China was issued in 1992 [14], which only specifies the properties of quick air lime (Table 1). According to this standard, building quick lime is graded into premium, first-class and satisfied. Yield of hydrated lime by wet slaking is a key 
Table 1 Chinese Building Lime Standard JC/T 481-1992

\begin{tabular}{|c|c|c|c|c|c|c|}
\hline \multirow[t]{2}{*}{ Grade } & \multicolumn{3}{|c|}{ Calcium quicklime } & \multicolumn{3}{|c|}{ Magnesium quicklime } \\
\hline & Premium & $\begin{array}{l}\text { First- } \\
\text { class }\end{array}$ & Qualified & Premium & $\begin{array}{l}\text { First- } \\
\text { class }\end{array}$ & Qualified \\
\hline Content of $\mathrm{CaO}+\mathrm{MgO}, \%$, no less than & 90 & 85 & 80 & 85 & 80 & 75 \\
\hline $\begin{array}{l}\text { Content of unslaked residue ( } 5 \mathrm{~mm} \text { round-hole residue on sieve), } \% \text {, no more } \\
\text { than }\end{array}$ & 5 & 10 & 15 & 5 & 10 & 15 \\
\hline $\mathrm{CO}_{2}, \%$, no more than & 5 & 7 & 9 & 6 & 8 & 10 \\
\hline Yield of lime hydrate, L/Kg, no less than & 2.8 & 2.3 & 2.0 & 2.8 & 2.3 & 2.0 \\
\hline
\end{tabular}

indicator for quality classification. Lime with hydraulic properties was neither notified, nor specified. Therefore, strictly speaking, the old Chinese lime standard restricts the research of building lime in China. It has been therefore proposed by conservators and administrators, the Chinese building lime standards should be updated, which may refer to European standards.

From 2009 laboratory tests and pilot production trials of natural hydraulic limes from various argillaceous limestones to limited scale have been launched [3], however until now there are no manufacturers of hydraulic limes in China, therefore currently all natural hydraulic limes for the research and application in China are imported either from France or from Germany.

\section{Lime for surface refitting, grouting and colouring}

There are a few research works carried out to develop grouting materials on the basis of natural hydraulic lime for structural purpose [15-18]. The results were controversy. It is however clear, due to high shrinkage, the mixture of natural hydraulic limes only with water is not suitable for grouting. They need to be modified with help of modern construction chemistry. From 2008, a system of new adhesives based on modified natural hydraulic limes has been developed. The system consists of 2 products; the first one is an adhesive for refitting and emergency re-bonding, with pull-off strength on marble substrate of app. $0.5 \mathrm{~N} / \mathrm{mm}^{2}$, after 28 days, can reach up to $1.0 \mathrm{~N} / \mathrm{mm}^{2}$ after app. 180 days. Second one is a grout with excellent flow properties for injection and cavity filling. Both formulations are already patented in China [5,6]. The practice to rescue Huashan Pictographs (Figure 1) and other natural stone monuments has proven their satisfied results. However, the durability and application under various climate zones need to be further studied.

Another important approach is to develop air lime with high bonding properties. The new air hydrated lime is produced under dispersion of calcium hydrate mixed with limited addition of Methyl cellulose and antifoaming agent [19]. Such dispersed lime with aforementioned formulation has very high adhesion strength (Table 2), which can not only be used as binder for restoration of mural paintings (Figure 7) and signs, but also as coloured lime paints both for interior and for exterior. To improve colour fastness of dispersed lime paints under outdoor weather condition, comparison tests using transparent solvent-based silane-siloxane solution and water-borne siloxane-wax dispersion as top sealer have been carried out. After app. 1 year exposure, the coloured lime paint sealed by water-borne siloxane-wax dispersion shows less colour change. The dispersed air lime shows wide range of application, for example, straw fibers and marble powder can also be mixed into it to restore marble-imitated ornaments (Figure 8).

\section{Lime-based restoration mortar for green bricks}

Over the past decades not only in China but also in Europe, restoration mortars were made from cement or organic resins [20], which are neither chemically nor

Table 2 Performance comparison of various dispersed air limes

\begin{tabular}{cccc}
\hline & Dispersed air lime, Type C & Dispersed air lime Type F & $\begin{array}{c}\text { Commercially available dispersed } \\
\text { lime from one German company }\end{array}$ \\
\hline $\begin{array}{c}\text { Solid content, wt\% } \\
\text { Aggregate content\% }\end{array}$ & 55 & 54 & 65 \\
$\begin{array}{c}\text { 7-day pull-off strength on marble } \\
\text { substrate/ carbonization depth } \\
\begin{array}{c}\text { 28-day pull-off strength on marble } \\
\text { substrate / carbonization depth } \\
\text { Capillary absorption coefficient }\left(\mathrm{kg} / \mathrm{m}^{2} \cdot \mathrm{h}^{0.5}\right)\end{array}\end{array}$ & $10 \%$ (white marble powder) \\
Chalking & $0.75 \mathrm{~N} / \mathrm{mm}^{2} / \leq 1 \mathrm{~mm}$ & $0.69 \mathrm{~N} / \mathrm{mm}^{2} / \leq 1 \mathrm{~mm}$ & $0.28 \mathrm{~N} / \mathrm{mm}^{2} / 3-4 \mathrm{~mm}$ \\
\hline
\end{tabular}




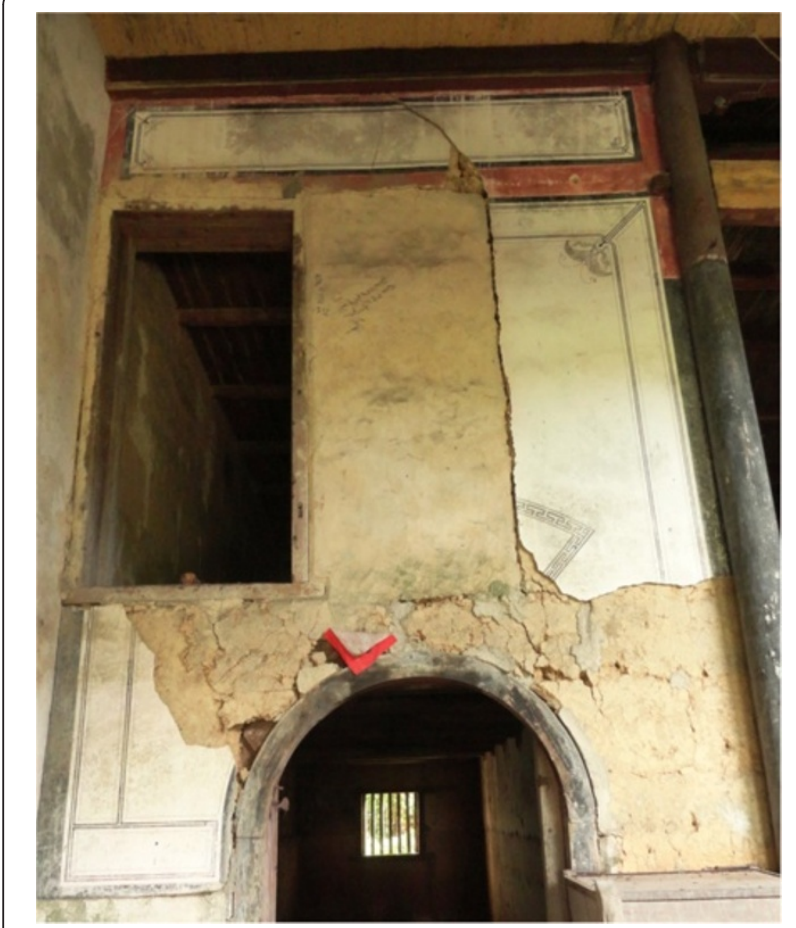

Figure 7 Mural painting of vernacular architecture (early $19^{\text {th }}$ century) on lime-earthen substrate in Jiangxi Province.

mechanically compatible with most of traditional soft Chinese grey-green bricks. More defects are caused by cement-based restoration mortar than natural influents (Figure 9).

In the pilot project jointly launched by Beijing Institute for Ancient Architecture and Tongji University [21], a special restoration mortar for green bricks has been developed. This lime restoration mortar is formulated with low strength, lower than deteriorated green bricks, and

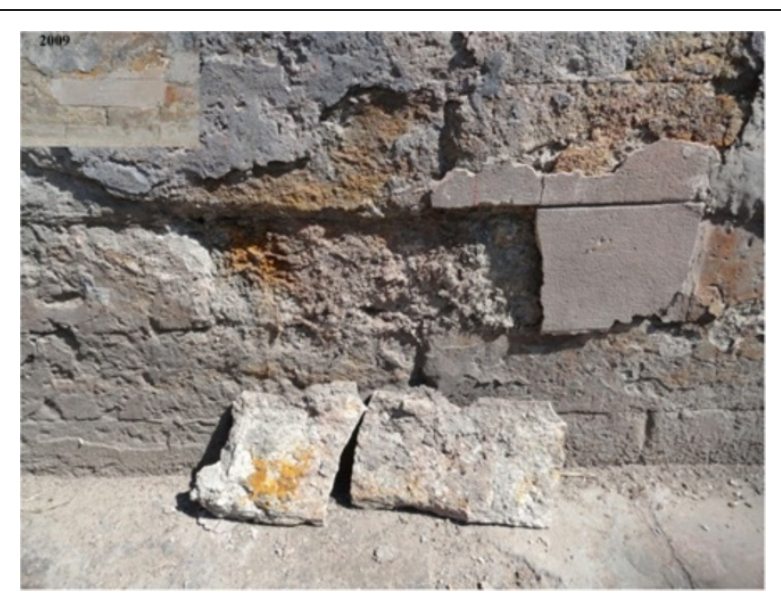

Figure 9 Cement-based mortar applied in 2002 to restore green bricks in Beijing, delaminated in 2012.

higher water absorption capacity and shall function as the sacrificial layer to conserve historic substances.

This mortar is composed of app. 18 wt\% NHL2 (Hessler Kalk Germany), app. 6 wt\% calcium hydrate (CL), app. 75 wt\% well graded crashed old bricks and limestone fillers and very small amount of Methyl cellulose, thixotropic agent, wood fiber, iron oxide pigments. All the components are premixed dry with help of dry mortar mixer than packed in $1 \mathrm{~L}$ containers. Conservators mix the powder with only water and/or small amount of iron oxide pigments to match individual stone on site.

After laboratory optimization, the mortar was applied in Beijing Xianlongtan (Figure 10) in 2012. Three locations with different orientation and moisture contents have been selected. The trial areas were restored as follows: the green bricks were desalinated 2 times with

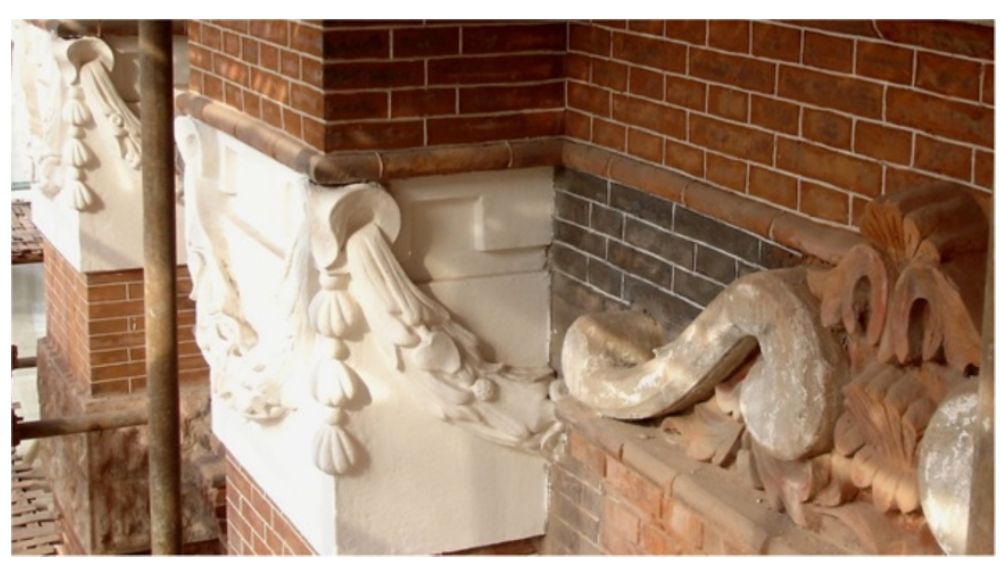

Figure 8 Strawed dispersed lime to restore marble imitated ornaments in Xuhui High School Shanghai (built in 1850). 


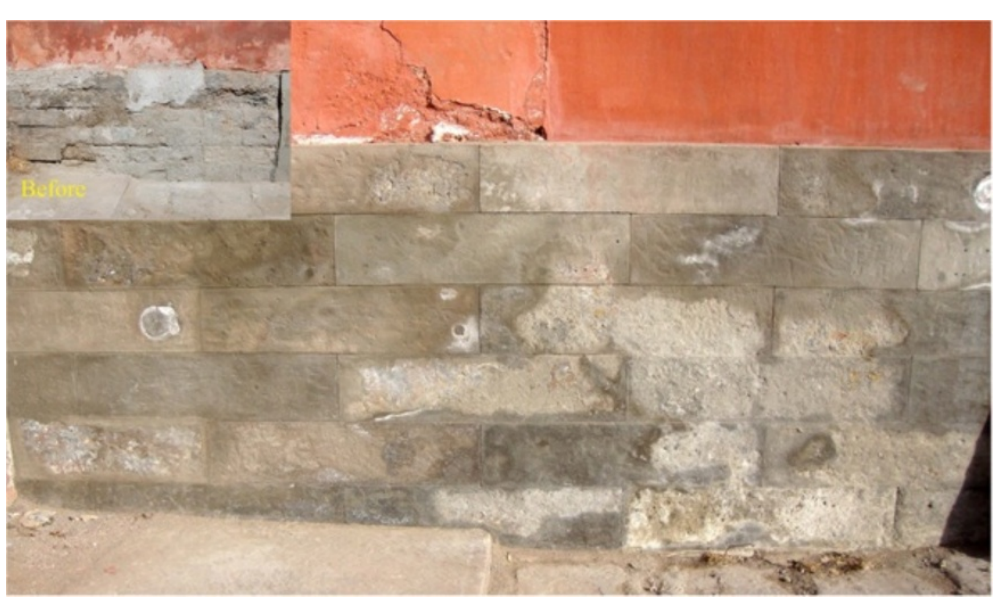

Figure 10 Trail to use lime to restore traditional Chinese green bricks (right after restoration).

cellulose-based poultice. The damaged bricks were then pre-wetted with table water and well mixed lime restoration mortar was applied with maximum thickness of 5$8 \mathrm{~mm}$. No water repellents have been applied.

Mechanical properties according to Chinese standard JGJ/T70-2009 [22] were tested, not under standardized climate condition rather under natural climate. Both compressive strength and flexural-tensile strength of the restoration mortar under dry weather in Beijing are higher than that under humid weather in Shanghai (Figure 11).

The trial areas were finished in middle May 2012 and app 10 months after accomplishment, visual finishing, colour, texture etc. were evaluated (Figure 12). The restored surface of 2 trial areas shows effloresces locally,

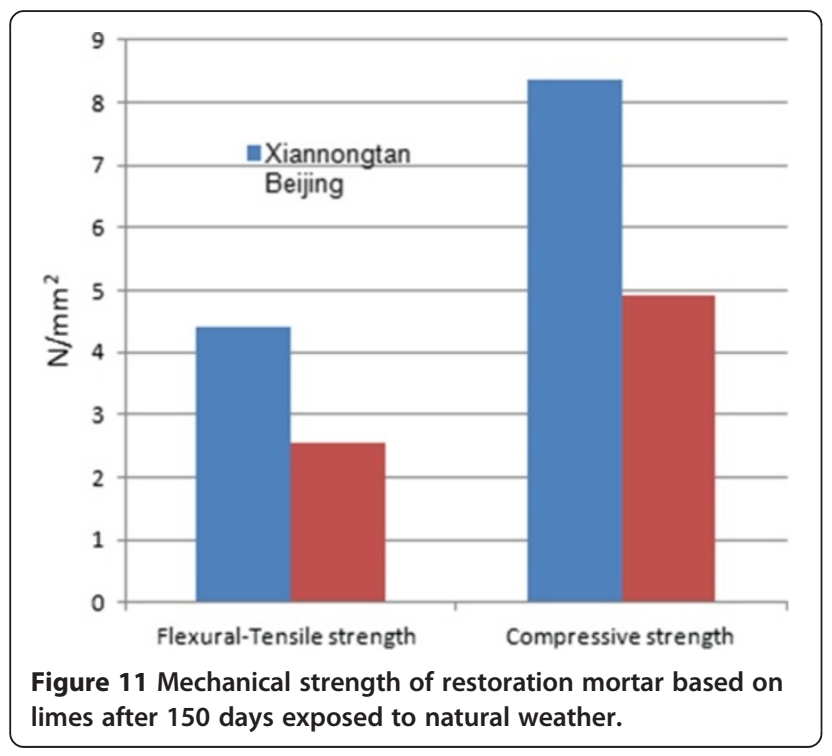

which may be typical phenomena of lime restoration mortar. All are crack-free, only one crack, more likely expansion crack, was found in the border between stone finishing and red plaster. This crack might be caused by salts from red plastered masonry. The capillary water absorption test with help of Karsten's Test Tube on site shows, the lime restoration mortar absorbs more water (Figure 13) than green bricks, while the drill resistance strength of the restoration mortar is app. $20 \%$ of that of solid green brick.

\section{Conclusions and discussion}

Lime has been used as a building and decoration material for thousands of years in China, but today it is no longer popular in new construction industry. In future,

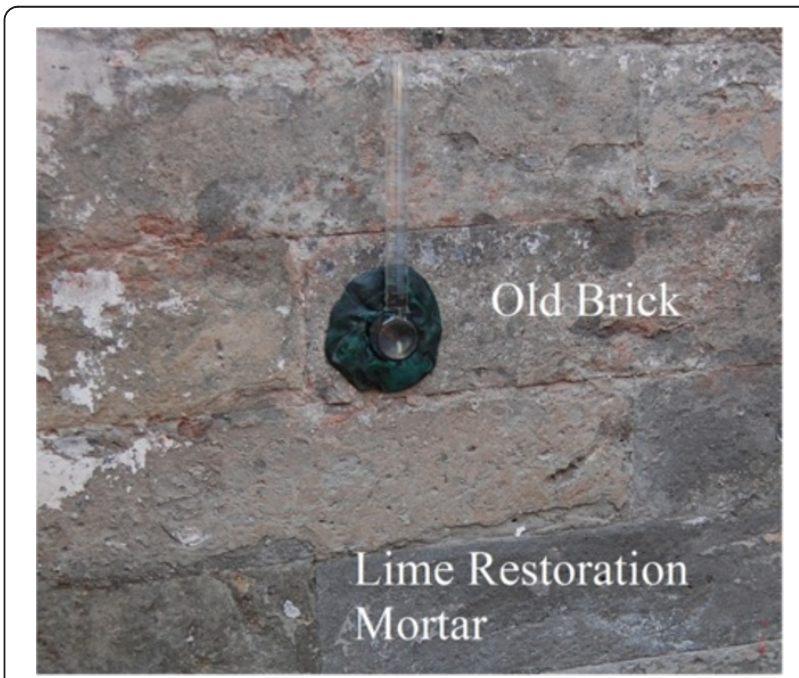

Figure 12 Evaluation of trial areas after app. 10 months exposure. 


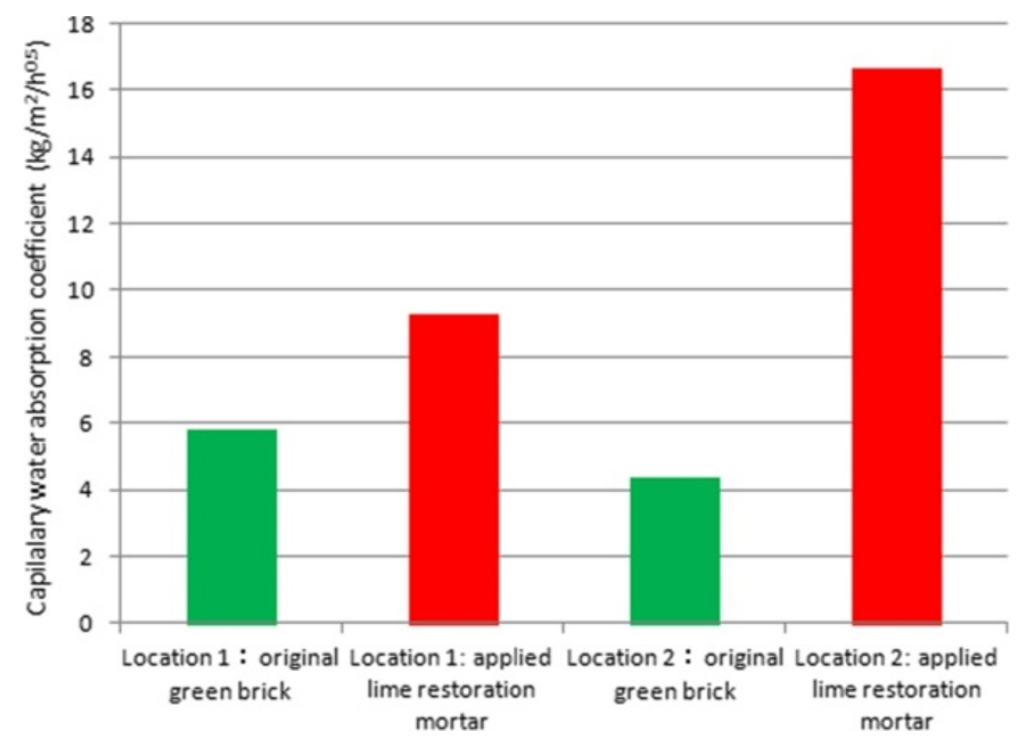

Figure 13 Capillary water absorption of green bricks and their restoration mortars on mock-up areas.

lime materials will be mainly used for the maintenance, restoration and conservation of historic architectures and cultural heritage. Most applied lime in history was wet slaked air lime, which was used as binder for masonry mortar or decorative plasters optimized with aggregates, fiber and natural organic resin (for example Tungoil). Lime is also used as stabilizer to consolidate earth in historic construction of city wall, roofing and earthen architecture. The traditional skills to slake and prepare lime are still being promoted in most of restoration and conservation projects.

Despite the same long history in the use of lime, China is far behind of Europe in the research of lime in modern times. Due to the wet slaking and lake of grinding technique, the ancient Chinese did not realize the hydraulic properties of limes, which can only be observed through dry slaking with or without grinding. Until 2008 natural hydraulic lime was introduced from Europe into China and has been researched comprehensively, but exclusively for conservation of cultural heritage. Adhesives, grouting slurries, restoration mortar for natural stones and kilned bricks (from traditional green bricks to firebricks) based on modified natural hydraulic limes (may be defined as formulated lime, FL, according to EN459-1 /2010) have been developed. With help of modern construction chemistry achievements, natural hydraulic limes can be modified to meet almost all kinds of requirements for conservation and restoration of cultural heritage. The new challenges will be grout to seal cracks from adobe and earthen masonry.

New research works in the future will be focused on comprehensive understanding the traditional Chinese lime skills scientifically (for example project granted No.
2012BAK14B05) and code of practice to transfer traditional lime skills to new generation.

More efforts will be done to understand the performance of lime under different climate and long term durability. Preliminary researches have shown, lime restoration mortar with the same formulations have different strength, NHL-based restoration mortar for green bricks has high strength in Beijing climate than in Shanghai. The reasons are not clarified.

\section{Competing interests}

The author declares that he has no competing interests.

\section{About the author}

Dr.rer. nat. Shi-bing Dai (1963- ), Professor at College for Architecture and Urban Planning Tongji University, Director of Architecture Conservation

Laboratory, specialized in building restoration and monument preservation.

\section{Acknowledgements}

This article is completed under the financial support of China National "Twelfth Five Years Key Research and Development Project granted No. 2012BAC11B01-2, the Architecture Conservation Laboratory (part of the of the Key Laboratory of Ecology and Energy-saving Study of Dense Habitat, Tongji University, Ministry of Education, PR China). The author thanks Wang Jinhua, Wang Yunfeng, Hu Yuan, Zhou Xiao, Dr. Li Li from China National Academy for Cultural Heritage in Beijing for fruitful collaboration within research projects on natural hydraulic limes and their application to consolidate stone monuments, which are funded by Ningming Cultural Bureau, Guangxi Autonomy and China National Bureau for Cultural Heritage. The author thanks also Dr. Huang Jizhong for collaboration of the research project in southern Shanxi Province. The author expresses deep appreciation Hang Yang, Zhang Tao from Beijing Institute for Ancient Architecture for constructive discussion on restoration of stone and green brick. The author also acknowledges Zhang Debing, Chen Guojun, Hu Zhanyong, Zhu Shangyou and Zhou Yuee for most of the laboratory testing and mock-ups in collaboration with Shanghai DS Building Materials Co. Ltd..

Received: 23 March 2013 Accepted: 3 July 2013

Published: 2 August 2013 
Reference

1. STRÜBEL, DAI \& WEBER Hrsg: Chinesisch-Deutsche Kooperation zur Konservierung der Yungang-Grotten. 1998. Symposium.

2. Strübel G, Kraus K, Kuhl O, Dettmering T: Hydraulische Kalke für die Denkmalpflege. Institut für Steinkonservierung e.V.Große Langgasse 29, 55116 Mainz, German: IFS Bericht Nr; 1998. ISBN Nr.0945-4748.

3. China National Academy for Cultural Heritage \& Shanghai DS Building Materials Co Ltd: Research Report on consolidation materials to refit the Huashan Pictographs. 2009. [R] (not published research report).

4. Dai SB, Wang JH: Lime-based Materials and Practices for Surface Refitting of Cultural Heritage in "Structural Analysis of Historic Constructions". In Edited by Xianglin G, Xiaobin S. Switzerland: Trans Tech Publications Inc; 2010. Ad. Materials Research Vols 133-134 at http://www.scientific.net. ISBN ISBN-13 978 -0-87849-239-8

5. China National Academy for Cultural Heritage \& Shanghai DS Building Materials Co Ltd: Patent: China. Beijing: State Intellectual Property Office of the PR China; 2012. No. ZL 201010158222.8.

6. China National Academy for Cultural Heritage \& Shanghai DS Building Materials Co Ltd: Patent: China. Beijing: State Intellectual Property Office of the PR China; 2012. No. ZL 201010158226.6

7. Zhou X, Hu Y, Wang J, Dai S: Application of Natural Hydraulic Lime for Refitting of Huashan Pictographs, Science of Conservation and Archaeology, No. 2. China: Editorial Board of Science of Conservation and Archaeology, Shanghai Museum; 2011. ISSN 1005-1538.

8. Du X: Restoration Technology of Traditional Chinese Ancient Buildings, 99 China: Architecture and Building Press; 1983.

9. Li Z: Architecture and Building Technology of Traditional Chinese Architecture 2nd edition. Shanghai, PR China: Tongii University Press; 2010:188-257.

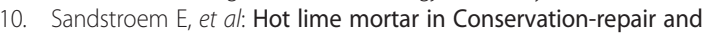
replastering of the façade of Laecko Castle. J Archit Conserv 2011, 17(1):95-118.

11. DAI S: Restoration of historic natural stones in the past decade in China -case study, in International Conference Human Resources Developement for transmission of Traditional skills natioanl approaches and their application to stone and brick. ACCU Nara 2011, 2012:171-176.

12. Kraus K: Kalkarten gestern und heute, in IFS-Bericht Nr. 19; Beitrage zur IFSTagung 2004 Kalkmörtel und Kalfarbe-Gestern, heute ... und morgen? (1-14). Institut für Steinkonservierung e.V. Große Langgasse 29, 55116 Mainz, Germany; 2004. ISSN-Nr.0945-4748.

13. BS EN 459-1: Building lime. Definitions, specifications and conformity criteria. UK: British-Adopted European Standard; 2011.

14. JC/T479-92: Building Quick Limes, Chinese Standard for Building materials. Beijing: State Construction Materials Bureau of the PR China; 1992.

15. JC/T479-92: Building Quick Limes, Chinese Standard for Building materials.

16. Pingarr'on A, Victoria I: Performance Analysis of Hydraulic Lime Grouts for Masonry Repair. University of Pennsylvania; 2006. Theses http://repository. upenn.edu/cgi/viewcontent.cgi?article=1013\&context=hp_theses.

17. Oezer F, Egloffstein P, Simon W: Sind Injektionsmörtel auf der Basis von natürlichem hydraulischem Kalk für die Instandsetzung von historischem Bauwerk geeignet? In Neue Erkenntnisse zu den Eigenschaften von NHLgebundenen Mörteln. Institut für Steinkonservierung e.V. Große Langgasse 29, 55116 Mainz, Germany; 2007. ISSN-Nr.0945-4748.

18. Oezer F, Egloffstein P, Simon W: Sind Injektionsmörtel auf der Basis von natürlichem hydraulischem Kalk für die Instandsetzung von historischem Bauwerk geeignet?. IFS Bericht; 2007. Neue Erkenntnisse zu den Eigenschaften von NHL-gebundenen Mörteln.

19. Tongji University \& Shanghai DS Building Materials Co Ltd, Patent Application No. 20100237183.0. China: State Intellectual Property Office of the PR China Beijing; 2010.

20. Rolf S: Leitfaden Steinkonservierung. Germany; 1997:94-95. ISBN 3-8167-4684-5.

21. Research report of Architecture Conservation Laboratory, Tongji Universitz: Research on restoration materials and method statements of Chinese traditional masonry in Beijing. 2013 (not published research report).

22. China Construction Standards JGJ/T70: Test Standard for Building Mortars. ; 2009.

doi:10.1186/2050-7445-1-25

Cite this article as: Dai: Building limes for cultural heritage conservation in China. Heritage Science 2013 1:25.

\section{Publish with ChemistryCentral and every scientist can read your work free of charge \\ "Open access provides opportunities to our colleagues in other parts of the globe, by allowing anyone to view the content free of charge." \\ W. Jeffery Hurst, The Hershey Company. \\ - available free of charge to the entire scientific community \\ - peer reviewed and published immediately upon acceptance \\ - cited in PubMed and archived on PubMed Central \\ - yours - you keep the copyright \\ Submit your manuscript here: \\ http://www.chemistrycentral.com/manuscript/<smiles>c1ccccc1</smiles> \\ Chemistry Central}

